\title{
MiFID Directive: Which Implementation within Belgian Financial Institutions
}

\author{
Loredana Cultrera ${ }^{1}$, Laetitia Pozniak ${ }^{1}$, Guillaume Vermeylen ${ }^{1}$ \\ ${ }^{1}$ Warocqué School of Business and Economics, University of Mons, Belgium \\ Correspondence: Loredana Cultrera, Warocqué School of Business and Economics, University of Mons, Place \\ Warocqué 17 - 7000 Mons, Belgium.
}

Received: May 24, 2017

doi:10.5539/ibr.v10n8p106
Accepted: July 3, $2017 \quad$ Online Published: July 11, 2017

URL: https://doi.org/10.5539/ibr.v10n8p106

\begin{abstract}
By relying on interviews with three financial institutions in Belgium, we determine how the MiFID directive has resulted in practice and how investors perceive these procedural changes. The results reveal some homogeneity between the three institutions both in determining the customer's risk, in the portfolio composition as in the appropriateness of the products sold to the investor's profile.
\end{abstract}

Keywords: MiFID, investors protection, investors profile, interviews, market in financial instruments

\section{Introduction}

The MiFID directive (2004/39/CE), i.e. Market in Financial Instruments Directive, published on the 30rd of April 2014 and entered into force on the 1st of November 2007, constitutes the new framework for the European market activities.

This directive relies on several objectives, influencing each other. The first one is to harmonize the rules that govern services and the exercise on investment activity. It extends the passport system provided to investment firms to new investments activities and investments services (Haas, 2007).

Henceforth, the accreditation granted by the Member State is sufficient, so that it is not anymore necess ary to ask for an additional accreditation and the host State may no longer impose its own requirements, as it was the case under the DSI directive (Buttigieg, 2007).

Once the passport system is harmonized and simplified through new licensing agreements, a transaction facility is created, allowing for greater competition within the European economic area. The second objective is to create a global regulatory framework aiming at the execution of orders in order to open up competition in Europe. That is, the Directive abolishes the market monopoly, which means that regulated markets no longer have a monopoly on financial products' trade in the European Union. Three main players have now to share the landscape of securities trading: The regulated markets (Art. 4(1)(14) of the Framework Directive), the multilateral trading systems (MTF) (Art. 4(1)(15) of the Framework Directive), and the systematic internalisers (IS) (Art. 4(1)(7) of the Framework Directive).

By means of the CESR database, it is possible to check this openness to competition. That is, the number of multilateral systems rose from 84 to 156 over the period July 1st 2007 to December 5th 2013. Over the same period, the number of systematic internalisers increased from 4 to 13 , and the one of regulated markets from 93 to 101. Focussing on the market shares of the different trading systems shows that even though regulated markets still occupy the most important place, the MTFs are tending to gain market shares in recent years (Hardt, 2009 and 2012). The competitive bidding in the trading venues aims therefore at achieving a genuine integrated market that benefits both to issuers and to investors and, ultimately, to the European economy. According to the European Commission, the Directive should reduce transaction costs by $0.5 \%$, boost employment by $0.5 \%$ and increase GDP by $1.1 \%$ (Milligan, 2007). Unfortunately, an increase in the markets fragmentation but also in liquidity pools was also expected (Tricou, 2007).

In order to avoid these potential issues when it enters into force, the directive has already strengthened and harmonized the rules of transparency required for the formation of the stocks. This brings the third objective which is to strengthen the pre- and post-trade transparency rules. It is appropriate to distinguish the pre and post-trade transparency rules: "Market transparency is the element that allows each investor to specify at which 
price he may/must make its investment, regarding the knowledge of the stocks and the intentions of other investors. The stocks of others are post-trade transparency. The intentions of others are the pre-negotiation transparency: at which prices and for which quantities of other instruments are they ready to make transactions?"(De Saint Mars, 2005). These rules, however, currently only concern the stocks.

Regulated markets and MTFs follow the same pre-trade transparency rules, i.e. they must make public the continuous supply and demand prices as well as the ability of the market to absorb purchase of sale orders on large amounts. There is virtually no change from the prevailing rules, except that they apply equally to MTFs (Soltani, Jerbi \& Minh Mai, 2011). However, the way to comply with these requirements will vary depending on the type of trading system used by the relevant market (European Union, 2006). Due to the riskier nature of their activity, systematic internalisers follow lighter rules of pre-negociation transparency than those previously cited. That is, they must publish firm buyer and/or seller prices only if three conditions are met, i.e. that (i) they are considered as systematic internalisers (Implementing Regulation 1287/2006); (ii) the shares are liquid (D'Hondt \& Giraud, 2008), and (iii) the transaction is not greater than the normal market size (Article 27 of the Framework Directive). The post-trade transparency rules, for their part, are simpler and identical for all actors. They must disclose some information such as the trading day of the transaction, the time of the transaction, the identifier of the relevant instrument or the price and the currency in which the price is denominated.

These different rules therefore have a simple purpose, allowing a transfer of information so that they are accessible for all and in a fair way so that the investor is better protected during the transaction. This element of protection is the central element of the Directive and we will consider it as the fourth objective. This research will be focused on this fourth objective.

In this paper, we try to understand how the MiFID directive is implemented in the Belgian financial institutions and how it is perceived by investors. To do so, qualitative research interviews are conducted (see section 2 below). The originality of this paper lies in the fact that it is based on semi-directive interviews carried out within the financial institutions in order to determine, on the one hand, the applications of the MiFID directive for the different stakeholders and, on the other hand, its practical implications in their organization. The main contribution of this study is to determine how a theoretical framework (in this case, a European reform) is applied in a concrete way in the concerned organizations (in this case financial institutions). We also try to check the compliance with the Directive and whether its requirements are met.

The results of our interviews with advisors from three financial institutions are then presented in Section 3. But first, the review of the literature (Section 1) is devoted to the presentation of MiFID elements that aim to protect investors.

\section{Literature Review}

\subsection{Investors Protection at the Heart of the MiFID Directive}

The objectives mentioned in the introduction reinforce the notion of investors protection. That is, through the expanded passport and the emergence of new trading platforms, the directive promotes efficient and competitive markets. The rules of transparency, for their part, guarantee the best execution of orders and the prices formation. Moreover, rules of conduct must be observed before, during and after the provision of services in order to guarantee the customer protection at any time during the transaction.

Regarding the heart of this directive, four main rules of conduct have to be observed: (i) knowledge of the client, (ii) Information to clients; (iii) Best execution policy and (iv) organizational rules.

The first rule of conduct, i.e. the knowledge of the client, is divided in two steps. The first step is to classify clients into three categories:

- The retail client, i.e. "a client who is not treated as a professional customer" (Article 4 (1) (10) of the Directive);

- The professional client, i.e. "a client who has some experience, knowledge and skills to make his own investment decisions and properly assess the risks"(Annex 2 of the Directive);

- The eligible counterpart, i.e. "a class of clients which may receive less protection than retail or professional clients, given their experience and well-established market practices" (Della Faille \& Servais, 2008).

The level of protection accorded to these different categories of clients is different. That is, the retail client will benefit from more protection than the professional one who will itself benefit from more protection than the eligible counterpart. The eligible counterpart is therefore the least well protected (Espin Gutierrez, 2007). It is 
however possible for them to change their category, at their request, either to benefit from better protection (opt-up) or sometimes from a lower protection (opt-down). However, this will have to be accepted by the regulated firm after the assessment of some criteria determining the client's ability to make its own investment decisions and its understanding of the risks involved (AMF, 2006; Casey \& Lannoo, 2009). In case of refusal, the client must contact another provider ready to provide the same services (Herbert \& Nasser, 2007).

The second step of this rule consists in testing the knowledge of the client. An adequacy test will be used when the investment firm provides either investment advices or portfolio management. This adequacy test consists in evaluating three criteria: investment objectives; financial position and investment knowledge and experiences (Weinberger, 2008). According to the definitions cited above regarding the classification of the clients, the retail clients will only be evaluated on the 3 criteria. Professional clients will have no questions about investment knowledge and experiences and the eligible counterparts will have no questions at all (Monte Paschi, 2007). The next test, the appropriate character test, is used during the supply of other investment services. This is the client who does not solicit advice and who has therefore to assume more of its decisions. This test consists in evaluating a single criterion: investment knowledge and experiences related to the type of product requested (Casey \& Lannoo, 2009). Only retail clients will be questioned in this test (CESR, 2008). Finally, the third test is the simple execution. This is not really a test but rather the situation where the orders are executed without any test or question so that the client supports all the responsibilities. In order to be able to meet this situation, certain conditions must be verified (Febelfin, 2007). All this, in the end, requires investment firms to act honestly, fairly and professionally, in order to serve the interests of the client in the best way possible.

Another rule of conduct imposed by the directive, which is designed to guarantee the highest level of client protection, is the provision of a wide range of information. The guiding principle of this rule is that the information that the company communicates is "correct, clear and not misleading" (Febelfin, 2007). The article 27 of the Implementing Directive specifies the conditions which the information must fulfill in order to be considered as correct, clear and not misleading. In addition, this information must be communicated on time, i.e. disseminated before or at the time of conclusion of the contract. In a non-exhaustive way, the following information must be disseminated:

- Advertising information(Della Faille \& Servais, 2008);

- Information on client categorization (Febelfin, 2007);

- Information about the company (Weinberger, 2008);

- Information on the nature of financial instruments and related risks (Weinberger, 2008);

- Information on costs and fees (CESR, 2008).

The FSMA must not approve the content and the form of information sent by a regulated firm to its clients or potential clients. It is therefore the task of the firm to be sure that it complies with the provisions of the Royal Decree of the 3rd of June 2007 related to information in order to guarantee the protection of its clients (Della Faille \& Servais, 2008).

A third rule of conduct is related to the principle of best execution. This principle had already been addressed in the Article 11 of the ISD Directive, but once again the wording of this rule was not precise and clear enough, resulting in different interpretations across Europe (Casey \& Lannoo, 2009, Iseli, Wagner \& Weber, 2007). From now on, the directive details how investment firms should carry out client orders to ensure the best possible execution (Dolhen, 2006). For retail clients with greater protection, the best result is determined on the basis of the sole criterion of the total counterpart, which represents the cost of the instrument and the costs associated to its execution (Karande, 2007). In any case, it is up to the firm to determine the relative importance of these different execution criteria (CESR, 2007; Ferrarini, 2007), the aim being for the firm to be able to demonstrate that each transaction is in line with its execution policy (Monte Paschi, 2007). That is, this rule constitutes an obligation of means, but not of result. However, this obligation only refers to the financial products covered by MiFID (Annex 1 of the Framework Directive). Also within the framework of this policy of best execution, the Article 19 (\$8) of the Directive requires investment firms to send to their clients 'adequate reports on the provided service'.

Still in the same willingness to improve client protection, the MiFID directive also imposes to investment firms a number of organizational rules. This latter rule of conduct obliges them to plan internally certain rules with which they must comply. The Article 13 of the Framework Directive defines the various organizational requirements and their content is specified in the Implementing Directive (Articles 5 to 25). These include requirements for general organization, risk management, handling of complaints, safeguarding of clients' assets 
or retention of data. Investment firms are therefore obliged to comply with all these requirements before providing a service to the client. As a result, the client is granting protection in all of the aforementioned matters and may enter into transactions with any investment firm that falls within the scope of the Directive and receives the same treatment.

\subsection{Mifid II}

This Directive, although undoubtedly the most structuring European legislative text of the last decade for all financial actors, required some revisions. For this reason, the Commission revised the text in the course of 2010 and proposed, on the 20th of October 2011 a new MiFID II directive together with a new regulation (MiFIR). A year later, in October 2012, the European Parliament adopted its own version followed by the Council of the European Union in June 2013. These revisions were due to end and had to be adopted by the end of 2013 so that a final application in all Member States by 2015 was effective but it is only on the 14th of January 2014 that the European Parliament and the Council have reached agreement on the updating of these rules. In May 2014 a report was published containing the main points raised during the discussion on the implementation of MiFID II. In view of the magnitude of the necessary changes and their difficulty, the changes are currently set to take effect from 3 january 2018. It requires a fundamental revision of companies' systems and procedures as well as changes in the structure of markets.

Five themes of revision were discussed. The first theme is the construction of stronger and more efficient market structures. For this, a new category of trading platform is born, organized trading systems. This is to ensure that all organized trading activities are conducted on regulated trading platforms (Bonduelle \& Amoyel-Arpino, 2012).

The second theme concerns the taking into account of technological innovation via a framework of algorithmic trading activities, including high frequency trading (European Union, 2011). Although HTF is known to improve the liquidity and efficiency of markets, questions are asked about the reality of this liquidity (Lehalle \& Burgot, 2010, Hautcoeur, Lagneau-Ymonet \& Riva, 2010).

The third theme concerns a greater transparency and therefore a transparency extends to other products than equities. The pre-negotiation transparency rules will be revised in order to counter the emergence of darks pools and the post-trade transparency rules will be coupled with a consolidated tape system, a continuous flow of information that should enhance data quality consistency.

The fourth theme is aimed at strengthening supervisory powers of the supervisory authorities and introducing a stricter framework for commodity derivatives markets (Barnier, 2010). Henceforth, they will be able to prohibit certain products or practices if they undermine the protection of investors (European Commission, 2011) and therefore apply sanctions and administrative measures such as the withdrawal of authorization (Proposal 2011/0298).

Finally, the last topic is devoted to improving investor protection through various measures described in the report of Fleuriot, Hellebuyck \& Poupart-Lafarge (2010).). It will be within the competence of the European Securities and Markets Authority (ESMA) to verify that these changes are applied uniformly and rigorously throughout Europe, so that investor protection is at the center of any negotiations.

MiFID II therefore seems to be one of the key pieces of financial market reform. Made up of two texts, a "MiFIR" regulation that focuses on market aspects and a directive "MiFID recast", oriented on rules of conduct, this directive is expected to change almost the entire market currently in place. The multiple strategic impacts that this new reform will introduce are thus sources of competitive advantages for those who go ahead, as well as a source of loss of income or market share for those who fail to react appropriately.

\section{Method}

To answer to our research question, we met three investment advisors from three financial institutions: BNP Paribas Fortis, Belfius and CBC, the biggest Belgian banks. We met three advisors of the same banks to ensure the consistency of the information gathered. We also tried to interview some customer advisors of ING Group bank but they all refused the interview. We also had an interview with a customer advisor of the CPH bank but as it is a cooperative bank, it is not constrained to the MiFID directive. In doing so, we contacted the five biggest Belgian banks, which gathers the majority of the Belgian financial area. The choice of the targeted interviewees has been done so that they were the firsts to be reached by MiFID and so the firsts that had to deal with it. This advisors had therefore the biggest background in such topic. The interviews took place between February and May 2013 and for the sake of confidentiality and anonymization of the replies received, bank advisors do not prefer their personal information to be disclosed. 
Semi-directional interviews, of about 45 minutes, were conducted in April and May 2013. Semi-directive interview is a qualitative study method based on individual interviews in which the interviewer only sets out the different topics that have to be covered. The interview is thus neither fully open nor completely directed; it is between the directional interview and the non-directional interview (Dereze, 2009).

Preference was given to this type of interview because it leaves the opportunity for the interviewee to develop her subject and to express herself freely, thus allowing her to deliver her feelings, opinions, reactions and perceptions on the different subjects from the questions asked (Patton, 2002). Interviews as qualitative research method is appropriate when the point of view of the actors is needed (Kyale, 1996; Daunais, 1992; Mayer, Ouellet, Saint-Jacques \& Turcotte, 2000).

The analysis is done according to the grounded theory (Glaser, Strauss \& Struzel, 1968) which consists in constructing a theory not from predetermined assumptions, but from data extracted from the field. The fundamental principle of this theory consists, from the data collected on a given subject, to seek without a priori what makes sense in the speech of the interviewees. Elements of discourse are thus identified through a series of specific coding extracted from the textual corpus and using a standardized procedure that is both inductive and comparative.

\section{Results}

The implementation of the Directive took place generally before its entry into force. BNP was the pioneer in implementing the directive. Belfius, for its part, carried out the theoretical application before its entry into force and practical application at the time of its entry into force. Concerning $\mathrm{CBC}$, in view of the workload that it involved practically, implemented it at the beginning of 2008. This implementation was carried out by the legal departments with the help of a few other departments, given the complexities involved in training staff and in contacting clients.

Indeed, all the advisers have received training on the functioning of the directive and on the use of the new tools in their possession. In addition, information was made available to familiarize everyone in contact with the Directive. These are mainly brochures and mails for customers and a computer platform for staff.

Concerning the application at the practical level, the first thing to do is to receive the client and explain the process. Belfius and BNP have included the Directive in a particular scheme, however, the first step, regardless of the institution, is the questionnaire. In theory, it is said that this questionnaire should include three types of questions, on the financial situation, investment objectives and knowledge and experience. For BNP and CBC, the questionnaire is perfectly subdivided in this way, unlike Belfius who asks questions about the client's financial situation and training only during this first step and asks the client about her investment objecti ves in a second step, and finally, questioned her knowledge and experience during the transaction.

Client risk aversion is assessed during suitability tests for BNP and $\mathrm{CBC}$ and during the portrait selection for Belfius. Indeed, at Belfius bank, the client chooses her portrait according to the portrait definition that suits her and her propensity to risk, unlike BNP and CBC who use a program to determine a profile. Stock selection is usually done through the IT tool that sorts the securities or sometimes via the product label or the risk class associated with each security. Finally, in terms of securities concentration, Belfius and CBC establish controls at the last stage before closing the transaction. The BNP bank verifies the concentration of the securities via a reference 'pie chart', which constitutes a more strict control. Once all these steps are completed, the advisors can proceed to the underwriting procedure. As for BNP, it will not stop there, it will continue with its other four stages which are purely commercial steps. They are used to target the customer's situation in its entirety and to propose accordingly their product range, so it is a sales strategy that fits in with the needs of the customer.

Although the questionnaire is not the same in the three institutions we met, it is clear from our interviews that all ask questions about the three types of domains, determine the risk propensity of the client, verify the composition of the portfolio and, finally, ensure that the products sold are in line with the portrait / profile. The application of MiFID is therefore relatively uniform in the three institutions encountered.

There is also a difference when the client does not want to answer questions or does not want to be advised. In this case, Belfius does not advise her and simply executes the orders. BNP and CBC give to the customer the lowest profile before executing the orders. Ultimately, in all three institutions, the client has to sign a document specifying her refusal of portrait / profile or specifying that she request a transaction without receiving advice to cover the bank in case of compliant or non-compliant product.

All of these changes resulted in mixed opinions with clients. Some were frightened by the changes, others bored by the questions and others reassured by this stricter framework. In any case, they were not really affected by the 
directive, unlike staff who were forced to perform additional tasks with a substantial administrative side. Indeed, from an administrative point of view, advisors must encode, give and sign more documents than before, and follow-up on the client's portfolio on a more regular basis. However, this customer relationship monitoring depends on one bank to another. Belfius operates mainly by segmentation, and at most the client has assets, at most it will have to be reviewed regularly. At BNP, the client is assigned to a customer manager who will receive follow-up messages in her daily tasks in order to contact the client regularly. Finally, at CBC, tracking will depend on the volume and quality of the client's portfolio. In any case, follow-up will generally be at least once or twice a year.

All these procedures and documents have been added for a particular reason, customer protection. All the banks say that the client's protection has been greatly improved. From now on, products can only be sold if they match the profile / portrait of the customer and that the entire portfolio is in adequacy. There is therefore a protection against inappropriate products. In addition, all documents provided improve transparency, like the policy execution, which is available in the bank branch for clients and which lists all the information relating to the transaction. Belfius says that overzealous manner are now limited, BNP mentions that its complaints have decreased and CBC says that they make self-checks regularly. Protection is therefore at the heart of all interview (Katz, 2007).

Differences exist between the before and after MiFID. For Belfius, the biggest difference is an awareness of the bank that it must pay more attention to what it markets. On the other hand, for BNP and CBC, the big difference comes from the practical application of the directive. As a result, their organization has been improved on a daily basis and the IT tools available provide a great help when selecting titles. Despite everything, one common thread that emerges is that today, customer satisfaction is privileged. However, in spite of these positive points, the advisers reveal that improvements can still be made and hope that they will appear with the MiFID II.

In conclusion, it can be argued that the application of MiFID has been uniform and therefore its implementation is a success. The only significant difference lies in the questionnaires and how to proceed with the various tests. Anyway, the impact on the customer was the same regardless of the institution as well as the impact on the advisor who had to face all sorts of technical and legal constraints. The three institutions encountered thus experienced the impact of this directive (Valiante \& Assi, 2011).

\section{Discussion}

The MiFID directive has succeeded in achieving its objectives in Belgium. The creation of a single market for financial activities is accomplished through the unique policy it has imposed throughout the European Union.

The objective of promoting the opening up to competition of European markets is also a success, but to a lesser extent. With the concept of the European passport, coupled with the legitimacy of MTFs and internalisation, it is now possible for any company concerned to carry out its activity or provide advice in any State, as long as it has an approval. Howe ver, the Directive has allowed the emergence of dark pools and crossing networks that have deteriorated the transparency of the markets, while transparency is also a key element.

The protection objective has also been achieved. Having imposed an identical legal framework on all the countries concerned and of having participated in the opening to competition that encourages exchanges to improve the quality of the services offered and / or to lower prices, go in line with a better protection of the customer. Moreover, the desire to create rules of transparency and best execution policy reinforces the idea, even if some rules are flawed. Interviews revealed that now customers are better protected from inappropriate products, however, even if the products sold match their profile, it does not change their intrinsic quality.

In particular, due to the aforementioned shortcomings, the Commission has foreseen a revision of the directive, a MiFID 2, with several revision topics including improved transparency and protection of customers.

In any case, it is early to pronounce as long as it is not effective, just as it is too early to decide on the effects of MiFID 1 which were probably absorbed by those of the 2008 financial crisis.

In addition to these general conclusions providing evidence to what is found in the literature concerning the implementation and the application in Europe, this study also demonstrates, thanks to our interviews, that the MiFID directive is applied in practice in the same way in the three institutions encountered in this research. All of them begin with the classification of the customer and no matter the type of profile, they are progressive and start with investments with guarantee of capital and interest rate as well as very little risk to finish without any guarantee with a lot of risk. In addition, each bank tests the suitability of the product with the profile / portrait of the client to ensure the correct composition of its portfolio of securities. To our knowledge, our study is the first to evaluate the implementation as well as the implications of the directive at the level of banks. 
The limit of this research lies in its exploratory nature and the limited number of interviews carried out. Evaluating the behavior of other countries could bring new or even contradictory elements. Moreover, the financial landscape is likely to change over time. The impacts of the Directive remain important but its real effect should only be felt in the long term. This study should therefore be repeated within a longer time horizon. Moreover, and although conducted in Belgium, this paper may be relevant for countries with similar financial and economical structure.

\section{References}

AMF. (2006). La directive sur les marchés d'instruments financiers : enjeux et conséquences pour la régulation française. Retrieve from http://www.amf-france.org/documents/general/6905_1.pdf

Barnier, M. (2010). Révision de la directive sur les Marchés d'Instruments Financiers, SPEECH/10/459. Retrieve from http://europa.eu/rapid/press-release_SPEECH-10-459_en.htm\#PR_metaPressRelease_bottom

Bonduelle, S., \& Amoyel-Arpino, V. (2012). Révision de la MiFID. Retrieve from http://www.next-finance.net/Revision-de-la-MIFID

Buttigieg, C. (2007). Understanding, transposing and implementing MiFID: What an ordeal! The Accountant, 42-47.

Casey, J. P., \& Lannoo, K. (2009). The MiFID Revolution. Cambridge University Press. https://doi.org/10.1017/CBO9780511770470

CESR. (2008). La directive MiFID: guide du consommateur - investir dans des produits financiers, CESR/08-003. Retrieve from http://www.cssf.lu/fileadmin/files/Protection_consommateurs/Guide_du_consommateur/CESR_guide_cons ommateur0308.pdf

CESR. Best Execution under MiFID - Questions \& Answers, CESR/07-320, Révision de la directive sur les Marchés d'Instruments Financiers, SPEECH/10/459. 2007. Retrieve from http://www.cmvm.pt/CMVM/Cooperacao\%20Internacional/Docs_ESMA_Cesr/Documents/07_320.pdf

D'Hondt, C., \& Giraud, J. R. (2008). MiFID Pre-Trade Transparency Rules: An Investor's Perspective. Journal of trading, 3(2), 8-17. https://doi.org/10.3905/jot.2008.705628

Daunais, J. P. (1992). L'entretien non directif. In Benoît Gauthier (dir.). Recherche sociale. Québec : Presses de l'Université du Québec, 273-293.

De Saint Mars, B. (2005). La transparence pré-négociation, Banque et droit, 102, 28-30.

Della Faille, P., \& Servais, J. P. (2008). La modernisation des marchés financiers, transposition en droit belge de la directive MiFID. Anthemis - Collection Affaires et Droit.

Dereze, G. (2009). Méthodes empiriques de recherche en communication. Éditions De Boeck Université.

Dolhen, P. E. (2006). Reporting réglementaire : 1'Europe est-elle prête à relever le défi MiFID ?. Revue Banque Pratique Bancaire et Financière, 686, 90-91.

Espin Gutierrez, C. (2007). La clasificación y la evaluación de los clientes-inversores en la reforma de la Ley del Mercado de Valores. Ekonomiaz-Revista vasca de economía, 66, 164-193.

European Union. (2006). Questions fréquemment posées concernant la directive MIF : mesures d'exécution de niveau 2 projetées. Mémo/06/57. Retrieve from http://europa.eu/rapid/press-release_MEMO-06-57_fr.htm?locale=fr

European Union. (2011). Review of the Markets in Financial Instruments Directive (MiFID): Frequently Asked Questions. Mémo/11/716. Retrieve from

http://europa.eu/rapid/press-release_MEMO-11-16_en.htm\#PR_metaPressRelease_bottom

Febelfin. (2007). MiFID en pratique ou ce qui va changer pour le client retail. Retrieve from http://www.febelfin.be/export/sites/default/febelfin/pdf/MiFID/BrochureRetail_FR.pdf

Ferrarini, G. (2007). Best Execution and Competition Between Trading Venues - MiFID's Likely Impact. Capital Markets Law Journal, 2(4), 404-413. https://doi.org/10.1093/cmlj/kmm026

Fleuriot, P., Hellebuyck, J. P., \& Poupart-Lafarge, O. (2010). La revision de la directive sur les Marchés d'Instruments financiers (MIF). Rapport au Ministre de l'Economie, de l'Industrie et de l'Emploi, 51

Haas, F. (2007). The Markets in Financial Instruments Directive: Banking on Market and Supervisory Efficiency. 
Working Paper, 1-24. https://doi.org/10.5089/9781451868135.001

Hardt, J. (2009). Global Challenges for regulators, FESE convention, Session 1, slide 6. Retrieve from http://www.fese.be/_lib/files/FESE_Convention_Judith_Hardt.pdf

Hardt, J. (2012). MiFID kongress - Regulatorisches Symposium am Dienstag, FESE speeches and reports, slide 9. Retrieve from http://www.fese.be/_mdb/speech/JH\%20-\%20MiFID\%20Kongress\%20-\%2013NOV12_7nov12_de.pdf

Hautcoeur, P. C., Lagneau-Ymonet, P., \& Riva, A. (2010). L'information boursière comme bien public : Enjeux et perspectives de la révision de la directive européenne 'marchés d'instruments financiers'. Revue d'économie financière, 98/99, 297-315. https://doi.org/10.3406/ecofi.2010.5798

Herbert, J., \& Nasser, B. (2007). La directive MIF, prochain séisme réglementaire dans le domaine du droit financier en Europe. Revue de Droit des Affaires Internationales, 3, 411-421.

Iseli, T., Wagner, A., \& Weber, R. (2007). Legal and economic aspects of best execution in the context of the Markers in Financial Instruments Directive (MiFID). Law and Financial Markets Review, 31-43.

Karande, K. (2007). MiFID Best Execution Benchmark. Working Paper, 1-16. https://doi.org/10.2139/ssrn.982952

Katz, E. (2007). MiFID - Practical issues for implementation. Law and Financial Market Review, 1, 5.

Kyale, S. (1996). Interviews: an introduction to qualitative research interviewing, Thousand Oaks, CA: Sage.

Lehalle, C. A., \& Burgot, R., (2010). Navigating Liquidity 4. Cheuvreux (Credit agricole group). Retrieve from https://www.cheuvreux.com/pdf/Navigating_Liquidity_september2009.pdf

Mayer, R., \& Ouellet, F., \& Saint-Jacques, M-C., \& Turcotte, D. (2000). Méthodes de recherche en intervention sociale. Boucherville : G. Editions Morin.

Milligan, R. (2007). MiFID shake-up: the specific effects, Europolitics, 3236, 29.

Monte, P. (2007). MiFID en pratique ou quels changements pour le Wholesale?. Retrieve from http://www.montepaschi.be/fr/pdf/MIFID3_Fr.pdf

Patton, M. G. (2002). Qualitative research and evaluation methods, Thousand Oaks, CA: Sage.

Proposition 2011/0298 (COD) de directive du Parlement européen et du Conseil, du 20 octobre 2011, concernant les marchés d'instruments financiers, abrogeant la directive 2004/39/CE du Parlement européen et du Conseil

Règlement (CE) 1287/2006 de la Commission, du 10 août 2006, portant sur les mesures d'exécution de la directive 2004/39/CE du Parlement européen et du Conseil en ce qui concerne les obligations des entreprises d'investissement en matière d'enregistrement, le compte rendu des transactions, la transparence du marché, l'admission des instruments financiers à la négociation et la définition de termes aux fins de ladite directive, J.O.U.E., $\mathrm{N}^{\circ}$ L241, du 2 septembre 2006, pp.1-25.

Soltani, B., Jerbi, M., \& Minh Mai, H. (2011). Transparency and Market Quality: An Analysis of the Effect of MiFID on Euronext. Working papers, 1-30. Retrieve from https://doi.org/10.2139/ssrn.1833605

Tricou, J. (2007). Banque d'investissement et de marché : la directive mif. Revue d'économie financière, 87, 43-53. https://doi.org/10.3406/ecofi.2007.4224

Valiante, D., \& Assi, B. (2011). MiFID Implementation in the Midst of the Financial Crisis: Results of an ECMI Survey. ECMI Research Report. No. 6.

Weinberger, M. D. (2008). Gestion de portefeuille et conseil en investissement : aspects contractuels et de responsabilités avant et après MiFID. Kluwer - Collection Pratique du Droit.

\section{Copyrights}

Copyright for this article is retained by the author(s), with first publication rights granted to the journal.

This is an open-access article distributed under the terms and conditions of the Creative Commons Attribution license (http://creativecommons.org/licenses/by/4.0/). 